\title{
Physical Properties of and Plant Responses to Rockwool-amended Media
}

\author{
William C. Fonteno ${ }^{1}$ and Paul V. Nelson ${ }^{2}$ \\ Department of Horticultural Science, North Carolina State University, Raleigh, NC 27695-7609 \\ Additional index words. growing media, root media, soil mixes, nutrition, Chrysanthemum $\times$ morifolium, Pelargonium \\ $\times$ hortorum, Impatiens sultana, Tagetes patula, Petunia hybrida, Lycopersicon esculentum, Euphorbia pulcherrima
}

\begin{abstract}
Loose rockwool had a total porosity similar to peatmoss (92\%, by volume) but with water retention capabilities similar to sand. Root media formulations containing loose rockwool were tested with seven plant species for plant response and nutrient uptake. The volume percent formulation, 20 rockwool : 10 peatmoss : 20 vermiculite : 45 pine bark : 5 perlite, was superior to formulations containing $10 \%$ or $30 \%$ rockwool. Plant response in this rockwool medium in bedding plant flats was superior to that in two high-performing commercial media for impatiens (Impatiens sultanii Hook), marigold (Tagetes patula L.), and petunia (Petunia hybrida Vilm) and equal to one commercial medium for tomato (Lycopersicon esculentum Mill.). However, response of chrysanthemum (Chrysanthemum $\times$ morifolium Ramat.), geranium (Pelargonium $\times$ hortorum Bailey), and poinsettia (Euphorbia pulcherrima Willd. ex Kl.) in 1.58-liter pots was inferior to both commercial media in one-half of the trials. Differential plant responses in the root media treatments did not relate directly to differences found to occur in plant nutrient composition. The high initial pH level of rockwool necessitated reduced application of limestone and increased application of calcium sulfate to offset Ca deficiency.
\end{abstract}

Rockwool is an inert, rock-based fibrous material used in the insulation industry. Rock, coke, and other materials are liquified at $1600 \mathrm{C}$, spun into fibers and used as "blowing wool insulation" or processed into various shapes with binders. Rectangular block forms manufactured with surfactant to increase wettability have been used successfully as root substrates for vegetable and cut flower production in Europe (Hamrick, 1985). Loose wool has been shown to have potential for containergrown plants both as a component in potting mixes (Hanan, 1983) and as a single component medium for geraniums (Lee and Goldsbury, 1988), pot chrysanthemums (Lee et al., 1987a), and poinsettia (Lee et al., 1987b). The objectives of this study 'were to examine the physical properties of rockwool and the plant growth response to media amended with loose rockwool.

\section{Materials and Methods}

Loose, nongranulated rockwool was obtained from Fibrex Inc. (Aurora, Ill.), with particles ranging from 3.2 to $.6 .4 \mathrm{~mm}$ in length. Four experimental formulations, similar in composition to nonrockwool-containing commercial mixes, were blended using various volumes of rockwool, Canadian sphagnum peat, U.S. grade 3 vermiculite, aged pine bark $(<13 \mathrm{~mm})$, and perlite Table 1). These were compared to two high-performing commercial root media, Metro Mix 350 (Grace-Sierra, Fogelsville, Pa.) and Ball Growing Mix II (Geo. J. Ball, W. Chicago, Ill.). The nutrient amendments to rockwool-containing media consisted of the following rates $\left(\mathrm{kg} \cdot \mathrm{m}^{-3}\right): 3.6$ dolomitic limestone, 0.6 gypsum, 0.5 phosphoric acid (85\%), 0.6 potassium nitrate, and 0.6 calcium nitrate in Expt. 1; and 1.8 dolomitic limestone, 1.2 gypsum, 0.5 phosphoric acid (85\%), 0.6 potassium nitrate, and 0.6 calcium nitrate in Expt.2. Inorganic micronutrients were

Received for publication 22 Feb. 1989. Paper no. 12026 of the Journal Series of the North Carolina Agricultural Research Service, Raleigh, NC 27695-7643. The use of trade names in this publication does not imply endorsement by the North Carolina Agricultural Research Service of the products named, nor criticism of similar ones not mentioned. The cost of publishing this paper was defrayed in part by the payment of page charges. Under postal regulations, this paper therefore must be hereby marked advertisement solely to indicate this fact.

${ }^{1}$ Associate Professor.

${ }^{2}$ Professor. sprayed on the media at the rates of $\left(\mathrm{g} \cdot \mathrm{m}^{-3}\right) 4.8 \mathrm{Fe}, 2.4 \mathrm{Mn}$, $2.4 \mathrm{Zn}, 2.4 \mathrm{Cu}$, and $1.0 \mathrm{~B}$.

Physicalproperties. Eight replications of six media were packed (Bilderback and Fonteno, 1987) in aluminum cylinders $(7.6 \times$ $7.6 \mathrm{~cm})$. Data were collected for moisture retained at 10 moisture tensions from 0 to $30 \mathrm{kPa}$ using a pressure plate apparatus and procedures of Fonteno et al. (1981), Karlovich and Fonteno (1986), and Milks et al. (1989a). After the measurement at 30 $\mathrm{kPa}$, each sample was removed and bulk density determined by calculating its volume and weighing each sample after it was dried $24 \mathrm{hr}$ at 105C (Klute, 1986).

A nonlinear, five-parameter function developed for soils by Van Genuchten and Nielsen (1985) and adapted to horticultural media by Milks et al. (1989a) was used to describe the moisture retention data. The function is defined as

$$
\Theta=\Theta_{\mathrm{r}}+\left(\Theta_{\mathrm{s}}-\Theta_{\mathrm{r}}\right) /\left[1+(\alpha \mathrm{h})^{\mathrm{n}}\right]^{\mathrm{m}}
$$

where $\theta_{S}$ is the mean percent moisture at saturation, $\theta_{r}$ is the mean percent moisture at asymptotic residual (taken to be 30 $\mathrm{kPa}$ ), $\mathrm{h}$ is the $\log$ of moisture tension, and $\alpha, \mathrm{n}$, and $\mathrm{m}$ are predicted through iteration.

Using similar packing techniques, four replications of media 4,5 , and 6 (Table 1) were packed in cylinders $2.2 \mathrm{~cm}$ tall. Data for moisture retained on a measured volume basis were collected at a moisture tension of $1500 \mathrm{kPa}$, according to Klute (1986) and Milks et al. (1989b).

Total porosity (TP) and unavailable water (UW) were equal to the volume wetness $(\theta)$ at saturation and $1500 \mathrm{kPa}$, respectively. Container capacity (CC) was predicted using the equilibrium capacity variables model developed by Bilderback and Fonteno (1987) and refined by Milks et al. (1989b). Air space (AS) was calculated as the difference between TP and CC. Available water (AW) was calculated as the difference between CC and UW (Milks et al., 1989b).

Plant growth. Two experiments were conducted to test plant response to rockwool-amended media. Experiment 1 consisted of all four rockwool-containing media, Metro Mix 350, and Ball Growing Mix II. Experiment 2 used only Ball II, Metro Mix 350 and medium 4 (20\% rockwool, $10 \%$ peatmoss, $20 \%$ vermiculite, $45 \%$ pine bark, and 5\% perlite). 'Yours Truly' geranium, 'Yellow Mandalay' pot chrysanthemum, and 'Dark Red 
Table 1. Root media formulations tested and the volume percentage of their components.

\begin{tabular}{|c|c|c|c|c|c|c|c|}
\hline \multirow[b]{2}{*}{ Medium } & \multicolumn{2}{|c|}{ Experiment } & \multicolumn{5}{|c|}{ Component } \\
\hline & 1 & 2 & Rockwool & Peatmoss & Vermiculite & Pinebark & Perlite \\
\hline & & & & Per & $e n t$ & & \\
\hline $\begin{array}{l}1 \\
2 \\
3 \\
4 \\
5 \\
6\end{array}$ & $\begin{array}{l}\mathbf{X} \\
\mathbf{X} \\
\mathbf{X} \\
\mathbf{X} \\
\mathbf{X} \\
\mathbf{X}\end{array}$ & $\begin{array}{l}\mathbf{X} \\
\mathbf{X} \\
\mathbf{X}\end{array}$ & $\begin{array}{l}10 \\
20 \\
30 \\
20 \\
\text { Ball Growing Mix Irz } \\
\text { Metro Mix 350y }\end{array}$ & $\begin{array}{r}10 \\
0 \\
0 \\
10\end{array}$ & $\begin{array}{l}25 \\
25 \\
20 \\
20\end{array}$ & $\begin{array}{l}50 \\
50 \\
45 \\
45\end{array}$ & $\begin{array}{l}5 \\
5 \\
5 \\
5\end{array}$ \\
\hline
\end{tabular}

${ }^{\mathrm{x}}$ Grace-Sierra, Foglesville, Pa.

${ }^{\mathrm{y}}$ Ball Seed Co. Div., Geo J. Ball, Inc., W. Chicago, Ill.

Annette Hegg' poinsettia were tested in each experiment. In addition, the bedding plants 'Spry Boy' marigold, 'Super Elfin Mix' impatiens, 'Special Grandiflora Mix' petunia, and 'Champion' tomato were tested in Expt. 2. The cultural schedules for these crops are presented in Table 2 . Rooted cuttings of chrysanthemum, geranium, and poinsettia were planted in 1.58-liter (17 cm, three-quarter height) plastic pots. Plug seedlings of the various bedding plants were planted in 48-cell plastic flats on indicated dates. Nutrient solutions used in this study consisted of the following macronutrient $(\mathrm{mM})$ and (micronutrient $(\mu \mathrm{M})$ concentrations: $25.7 \mathrm{NO}_{3}^{-}, 17.2 \mathrm{NH}_{4}^{+}, 4.2 \mathrm{PO}_{4}^{-}, 12.8 \mathrm{~K}^{+}, 54$ $\mathrm{Fe}^{2+}, 31 \mathrm{Mn}^{2+}, 0.76 \mathrm{Zn}^{2+}, 4.7 \mathrm{Cu}^{2+}, 4.7 \mathrm{Cu}^{2+}, 56 \mathrm{BO}_{3}^{-3}$, and $3 \mathrm{MoO}_{4}^{-}$. This fertilizer was applied weekly to chrysanthemum and poinsettia plants at full strength, weekly to geranium plants at $80 \%$ strength, and to bedding plants at $40 \%$ strength 5,12 , and 26 days after plug seedlings were planted. Additional nutrients were applied to poinsettia plants in Expt. 1 at 34 days after planting as a spray of $0.15 \mathrm{~g} \mathrm{Na}_{2} \mathrm{MoO}_{4} \cdot 2 \mathrm{H}_{2} \mathrm{O} /$ liter $(60 \mathrm{mg}$ $\mathrm{Mo} /$ liter) and to chrysanthemums in Expt. 1 at 36 days after planting as a drench of $0.3 \mathrm{~g} \mathrm{FeSO}_{4} \cdot 7 \mathrm{H}_{2} \mathrm{O} /$ liter $(60 \mathrm{mg} \mathrm{Fe} / \mathrm{liter})$. Water was applied for each medium-species combination as needed, with $15 \%$ to $25 \%$ excess fluid. The greenhouse night heating set point was $17 \mathrm{C}$ and the day set point was $24 \mathrm{C}$.

Root media and leaf samples were collected on the dates indicated in Table 2. In all cases, the youngest, fully expanded leaves were sampled. Leaf tissue was washed for $1 \mathrm{~min}$ in 0.2 $\mathrm{N} \mathrm{HCl}$, rinsed in distilled water, and ground in a stainless steel Wiley mill to a particle size $\leq 1 \mathrm{~mm}$ (20-mesh screen). Tissue used for $\mathrm{P}, \mathrm{K}, \mathrm{Ca}, \mathrm{Mg}, \mathrm{S}, \mathrm{Fe}, \mathrm{Mn}, \mathrm{Zn}$, and $\mathrm{Cu}$ analyses was dry-ashed at 500C, dehydrated in $\mathrm{HCl}$ and finally dissolved in $0.5 \mathrm{~N} \mathrm{HCl}$. Tissue used for $\mathrm{S}$ and $\mathrm{B}$ analysis was handled in a similar manner, except that it was ashed in the presence of a solution of magnesium nitrate in methanol. Total $\mathrm{N}$ was determined by a Kjeldahl procedure that included a salicylic acid pretreatment to aid reduction of nitrate (Eastin, 1978). Analysis of $\mathrm{K}, \mathrm{Ca}, \mathrm{Mg}, \mathrm{Fe}, \mathrm{Mn}, \mathrm{Zn}$, and $\mathrm{Cu}$ was by means of atomic absorption spectrophotometry. A turbidometric procedure was used for $\mathrm{S}$ in which barium sulfate was suspended with poly-

Table 2. Cultural schedule for the various crops tested in the two experiments.

\begin{tabular}{|c|c|c|c|c|}
\hline Procedure & Geranium & Chrysanthemum & Poinsettia & Bedding plants \\
\hline $\begin{array}{l}\text { Plant } \\
\text { Spacing (cm) } \\
\text { Remove terminal bud } \\
\text { Long day treatment } \\
\text { Chlormequat spray } \\
\text { Daminozide spray } \\
\text { Remove lateral buds } \\
\text { Sample soil } \\
\text { Sample leaves } \\
\text { Final data }\end{array}$ & $\begin{array}{l}26 \text { Oct., } \\
25 \text { Nov., } 19 \text { Dec. } \\
27 \text { Nov. } \\
19 \text { Dec. }\end{array}$ & $\begin{array}{l}\text { Experiment } 1^{2} \\
21 \text { Dec. } 1985 \\
36 \\
5 \text { Nov. } \\
21 \text { Oct. to } 5 \text { Nov. } \\
8 \text { Nov. } \\
17 \text { Dec. } \\
4 \text { Nov., } 5 \text { Dec., } \\
10 \text { Jan. } \\
6 \text { Dec. } \\
10 \text { Jan. } 1986\end{array}$ & $\begin{array}{l}26 \text { Sept. } 1985 \\
43 \\
9 \text { Oct. } \\
26 \text { Sept. to } 25 \text { Oct. } \\
18 \text { Nov., } 2 \text { Dec. } \\
26 \text { Oct., } 25 \text { Nov., } \\
10 \text { Jan. } \\
27 \text { Nov. } \\
10 \text { Jan. } 1986\end{array}$ & . \\
\hline $\begin{array}{l}\text { Plant } \\
\text { Spacing (cm) } \\
\text { Remove terminal bud } \\
\text { Long day treatment } \\
\text { Chlormequat spray } \\
\text { Daminozide spray } \\
\text { Remove lateral buds } \\
\text { Sample soil }\end{array}$ & $\begin{array}{l}10 \text { Apr. } 1986 \\
34 \\
25 \text { Apr. } \\
9 \text { May } \\
25 \text { Apr., } 2 \text { June }\end{array}$ & $\begin{array}{l}\text { Experiment } 2 y \\
10 \text { Apr. } 1986 \\
36 \\
10 \text { Apr. to } 1 \text { May } \\
5 \text { May } \\
4 \text { June } \\
25 \text { Apr., } 21 \text { May, } \\
2 \text { July }\end{array}$ & $\begin{array}{l}28 \text { May } 1986 \\
36 \\
4 \text { June- } \\
28 \text { May to } 25 \text { June } \\
18 \text { June }\end{array}$ & $\begin{array}{l}18 \text { Apr. } \\
25 \text { Apr., } 14 \text { May } \\
14 \text { Mav }\end{array}$ \\
\hline $\begin{array}{l}\text { Sample leaves } \\
\text { Final data }\end{array}$ & $\begin{array}{l}2 \text { June } \\
2 \text { June }\end{array}$ & 2 July & $\begin{array}{l}4 \text { Sept. } \\
4 \text { Sept. }\end{array}$ & 14 May \\
\hline
\end{tabular}


vinyl pyrolidine (A.H. Hunter, personal communication). Colorimetric analyses were performed for P (Jackson, 1958) and B (Grinstead and Snider, 1967) and a UV/VIS spectrophotometer.

Root media were extracted by means of the saturated soil extract procedure (Warncke, 1986). The $\mathrm{pH}$ levels were determined directly on this extract. Colorimetric procedures were applied to this extract for nitrate (Cataldo et al., 1975) and for ammonium (Chaney and Marbach, 1962). Urea was determined by the difference in results of ammonium analysis including and omitting urease from the test procedures (Chaney and Marbach, 1962).

Plant height was measured from the root medium surface to the top of bracts or flowers for poinsettia and chrysanthemum, the top of the foliage for geranium, and to the average top of plants, including blooms, in entire flats for bedding plants. Plant diameters consisted of the average of two measurements made at right angles. Individual plant diameter was measured for geranium and poinsettia, while, for chrysanthemum, it was the collective diameter of all five plants in each pot. Fresh-weight measurements were made on the above-ground portions of plants only. Values reported are the average per plant weights of five chrysanthemum plants from a given pot, one geranium, one poinsettia, or 23 plants from each species of bedding plant. The number of geranium shoots included only those $8 \mathrm{~cm}$ or longer. Bract diameter of poinsettia included the diameter of the total bract mass on a given stem.

A randomized complete block experimental design was used consisting of six root media treatments, three species, and four blocks with six plants per plot in Expt. 1; in Expt. 2, three root media treatments, seven plant species, and six blocks with six plants per plot, or, in the case of bedding plants, one flat per plot, were involved. Data were subjected to an analysis of variance; where treatments effects were found, means were separated by the LSD test.

\section{Results and Discussion}

The moisture retention data for rockwool was regressed against moisture tension and compared to other more traditional components of container media (Fig. 1). Rockwool held 92\% (by volume) of water at saturation $(0 \mathrm{kPa})$, similar to Canadian sphagnum peat. However, rockwool lost water very quickly as

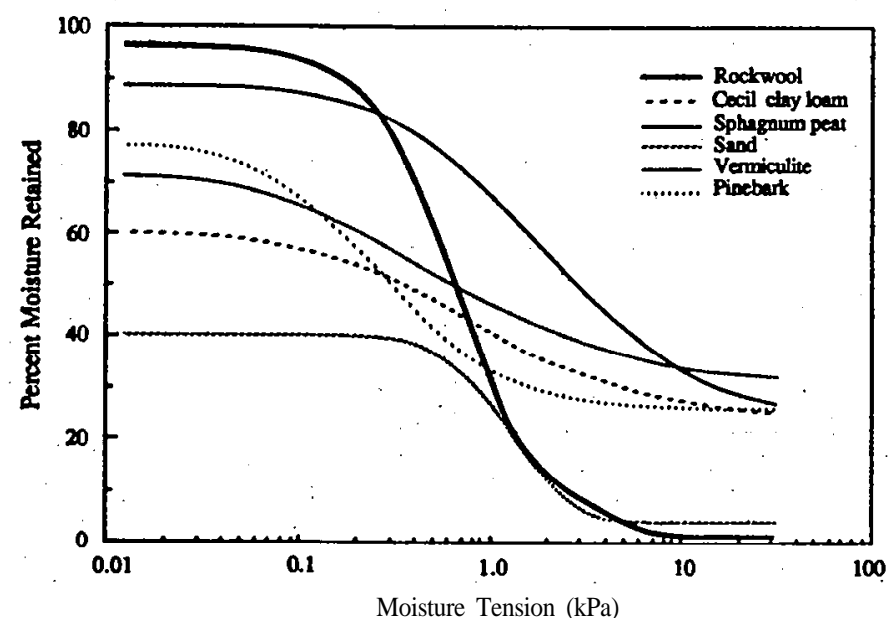

Fig. 1. Moisture retention curves (from 0 to $30 \mathrm{kPa}$ ) for rockwool (3.2- to 6.4-mm particles), Cecil clay loam, Canadian sphagnum peat, concrete grade sand, horticultural grade vermiculite, and aged pine bark $(<13 \mathrm{~mm})$. pressure was applied and held only $\approx 2 \%$ moisture (by volume) at pressures $\geq 10 \mathrm{kPa}$. The ability of rockwool to hold water will vary with the size of the container. These data indicate that water content decreases faster in rockwool with increasing height above the container bottom than in peatmoss. Thus, similar water availability but much better aeration at the top of the container could exist for rockwool. This is an interesting new characteristic for potting media and may provide greater flexibility in their formulation. Sand has a similar drop-off in water content as rockwool, but does not hold as much water. Rockwool may provide unique moisture retention characteristics when blended with other medium components.

Additions of $10 \%$ to $30 \%$ (by volume) of rockwool to blends of other components (media 1-4) produced very similar moisture retention curves. Moisture retention characteristics of medium 4 (with 20\% rockwool), Metro Mix 350, and Ball Growing Mix II are shown in Fig. 2. Generally, the rockwool-containing media held slightly less water at all pressures from 0 to $30 \mathrm{kPa}$ than the other two media. However, we judged the water retention properties of the rockwool-containing media as very good, similar to other commercially available media. Total porosity for the rockwool mixes ranged from $78 \%$ to $81 \%$, while the commercial mixes were both $84 \%$.

In Expt. 1, variation of rockwool percentage did not alter the air- and water-holding capacities among media 1 through 4. Medium 4 was then used again in Expt. 2 with Ball Growing Mix II and Metro Mix 350. In the 1.58-liter container, container capacity of the rockwool medium was $5 \%$ lower than that for Ball Growing Mix II and 20\% lower than that for Metro Mix 350 (Table 3 ). The rockwool mix provided good air space $(21 \%)$, similar to Ball Growing Mix II, while Metro Mix 350 provided slightly less. All three media held about the same amount of water beyond $1.5 \mathrm{MPa}(23 \% \pm 1 \%)$. While this unavailable water content was high compared to mineral field soil, it is typical of other organic media (Milks et al., 1989b). Available water content ranged from $34 \%$ to $44 \%$ for the three media.

Total porosity and unavailable water are not functions of container size and therefore were not different in the bedding plant (BP) cells from values in the 1.58-liter containers (Table 3). Container capacity, available water, and air space are affected by container height and changed in the shorter container (Klute, 1986). Container capacities ranged from $70 \%$ to $78 \%$ (Table 3 ). Air space in the BP cell was reduced by one-half in the rockwool

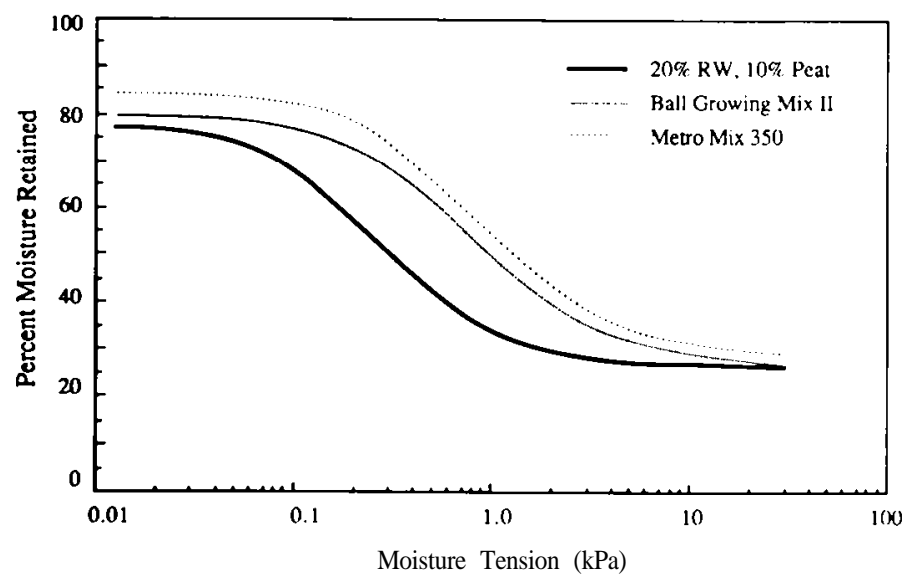

Fig. 2. Moisture retention curves (from 0 to $30 \mathrm{kPa}$ ) for a rockwool (RW)-containing medium (20\% rockwool, $10 \%$ peatmoss, $20 \%$ vermiculite, $45 \%$ pine bark, $5 \%$ perlite), Ball Growing Mix II, and Metro Mix 350. 
Table 3. Physical characteristics of rockwool-containing and commercial mixes in 1.58-liter pot and bedding plant cell (BP); (48 cell/tray).

\begin{tabular}{|c|c|c|c|c|c|c|c|}
\hline Medium $^{z}$ & $\begin{array}{c}\text { Rockwool } \\
(\%)\end{array}$ & Container & $\begin{array}{l}\text { Total } \\
\text { rosity } \\
\text { (TP) }\end{array}$ & $\begin{array}{c}\text { Container } \\
\text { capacity }^{\mathrm{x}} \\
(\mathrm{CC})\end{array}$ & $\begin{array}{c}\text { Unavailable } \\
\text { water }^{\mathrm{w}} \\
\text { (UW) }\end{array}$ & $\begin{array}{c}\text { Available } \\
\text { water } \\
\text { (AW) }\end{array}$ & $\begin{array}{c}\text { Air } \\
\text { Space }^{u}\end{array}$ \\
\hline 1 & 10 & $\begin{array}{l}\text { Pot } \\
\text { BP }\end{array}$ & $\begin{array}{l}78.5 \\
78.5\end{array}$ & $\begin{array}{l}57.2 \\
68.0\end{array}$ & & & $\begin{array}{l}21.3 \\
10.5\end{array}$ \\
\hline 2 & 20 & $\begin{array}{l}\text { Pot } \\
\text { BP }\end{array}$ & $\begin{array}{l}81.4 \\
81.4\end{array}$ & $\begin{array}{l}58.2 \\
69.2\end{array}$ & & & $\begin{array}{l}23.2 \\
12.2\end{array}$ \\
\hline 3 & 30 & $\begin{array}{l}\text { Pot } \\
\text { BP }\end{array}$ & $\begin{array}{l}79.5 \\
79.5\end{array}$ & $\begin{array}{l}56.0 \\
67.1\end{array}$ & & & $\begin{array}{l}23.5 \\
12.4\end{array}$ \\
\hline 4 & 20 & $\begin{array}{l}\text { Pot } \\
\text { BP }\end{array}$ & $\begin{array}{l}79.7 \\
79.7\end{array}$ & $\begin{array}{l}58.3 \\
69.5\end{array}$ & $\begin{array}{l}24.3 \\
24.3\end{array}$ & $\begin{array}{l}34.0 \\
45.2\end{array}$ & $\begin{array}{l}21.4 \\
10.2\end{array}$ \\
\hline 5 & 0 & $\begin{array}{l}\text { Pot } \\
\text { BP }\end{array}$ & $\begin{array}{l}84.3 \\
84.3\end{array}$ & 62.5 & $\begin{array}{l}24.5 \\
24.5\end{array}$ & $\begin{array}{l}38.0 \\
49.4\end{array}$ & $\begin{array}{l}21.8 \\
10.4\end{array}$ \\
\hline 6 & 0 & $\begin{array}{l}\text { Pot } \\
\text { BP }\end{array}$ & $\begin{array}{l}84.3 \\
84.3\end{array}$ & $\begin{array}{l}66.6 \\
77.6\end{array}$ & $\begin{array}{l}22.5 \\
22.5\end{array}$ & $\begin{array}{l}44.1 \\
55.1\end{array}$ & $\begin{array}{r}17.7 \\
6.7\end{array}$ \\
\hline
\end{tabular}

${ }^{\mathrm{z}}$ Medium descriptions listed in Table 1.

${ }^{\mathrm{y}}$ Percent volume at $0 \mathrm{kPa}$.

${ }^{\mathrm{x}}$ Predicted as percent volume at drainage.

${ }^{\mathrm{w}}$ Percent volume at $1.5 \mathrm{MPa}$.

${ }^{v} \mathrm{C} C-\mathrm{U}$ W.

${ }^{\mathrm{u}} \mathrm{TP}-\mathrm{CC}$.

Table 4. Effect of root media treatments on characteristics of 'Yellow Mandalay' pot chrysanthemum. ${ }^{2}$

\begin{tabular}{|c|c|c|c|c|c|c|c|c|c|c|c|}
\hline \multirow[b]{3}{*}{ Medium } & \multirow{3}{*}{$\begin{array}{c}\text { Rockwool } \\
(\%)\end{array}$} & \multicolumn{10}{|c|}{ Experiment } \\
\hline & & 1 & 2 & 1 & 2 & 1 & 2 & 1 & 2 & 1 & 2 \\
\hline & & \multicolumn{2}{|c|}{ Height $(\mathrm{cm})$} & \multicolumn{2}{|c|}{ Width $(\mathrm{cm})$} & \multicolumn{2}{|c|}{ Fresh wt (g) } & \multicolumn{2}{|c|}{ Flower (No.) } & \multicolumn{2}{|c|}{ Quality rating $^{\mathrm{y}}$} \\
\hline $\begin{array}{l}1 \\
2 \\
3 \\
4 \\
5 \\
6\end{array}$ & $\begin{array}{r}10 \\
20 \\
30 \\
20 \\
0 \\
0\end{array}$ & $\begin{array}{l}22.8 \mathrm{bc} \\
22.7 \mathrm{c} \\
21.5 \mathrm{~d} \\
23.2 \mathrm{bc} \\
23.4 \mathrm{~b} \\
24.6 \mathrm{a}\end{array}$ & $\begin{array}{l}26.9 \mathrm{~b} \\
26.7 \mathrm{~b} \\
28.5 \mathrm{a}\end{array}$ & $\begin{array}{l}41.3 \mathrm{dc} \\
41.8 \mathrm{~cd} \\
40.3 \mathrm{e} \\
42.8 \mathrm{bc} \\
43.4 \mathrm{~b} \\
45.3 \mathrm{a}\end{array}$ & $\begin{array}{l}50.8 \\
50.6 \\
52.2\end{array}$ & $\begin{array}{l}21.1 \mathrm{c} \\
23.7 \mathrm{ab} \\
22.2 \mathrm{c} \\
23.0 \mathrm{bc} \\
24.9 \mathrm{a} \\
24.6 \mathrm{a}\end{array}$ & $\begin{array}{l}26.0 \mathrm{~b} \\
24.5 \mathrm{~b} \\
28.9 \mathrm{a}\end{array}$ & $\begin{array}{l}34.2 \mathrm{c} \\
35.3 \mathrm{c} \\
31.3 \mathrm{~d} \\
36.1 \mathrm{c} \\
38.3 \mathrm{~b} \\
43.1 \mathrm{a}\end{array}$ & $\begin{array}{l}56.7 \mathrm{~b} \\
53.5 \mathrm{~b} \\
61.6 \mathrm{a}\end{array}$ & $\begin{array}{l}3.8 \mathrm{c} \\
3.7 \mathrm{c} \\
2.9 \mathrm{~d} \\
4.3 \mathrm{~b} \\
4.6 \mathrm{ab} \\
4.8 \mathrm{a}\end{array}$ & $\begin{array}{l}4.5 \mathrm{~b} \\
4.3 \mathrm{~b} \\
5.0 \mathrm{a}\end{array}$ \\
\hline
\end{tabular}

${ }^{\mathrm{z}}$ Mean separation in columns by LSD test, $P=0.05$. No significant difference-s in column without letters.

${ }^{\mathrm{y}} 1=$ poor, 5 = excellent quality.

Table 5. Effect of root media treatments on characteristics of 'Yours Truly' geranium. ${ }^{\mathrm{z}}$

\begin{tabular}{|c|c|c|c|c|c|c|c|c|c|c|}
\hline \multirow[b]{3}{*}{ Medium } & \multirow{3}{*}{$\begin{array}{c}\text { Rockwool } \\
(\%)\end{array}$} & \multicolumn{9}{|c|}{ Experiment } \\
\hline & & 1 & 2 & 1 & 2 & 1 & 2 & 1 & 2 & 2 \\
\hline & & \multicolumn{2}{|c|}{ Height $(\mathrm{cm})$} & \multicolumn{2}{|c|}{ Fresh wt (g) } & \multicolumn{2}{|c|}{ Shoot (No.) } & \multicolumn{2}{|c|}{ Quality rating $^{\mathrm{y}}$} & Width $(\mathrm{cm})$ \\
\hline $\begin{array}{l}1 \\
2 \\
3 \\
4 \\
5 \\
6\end{array}$ & $\begin{array}{r}10 \\
20 \\
30 \\
20 \\
0 \\
0\end{array}$ & $\begin{array}{l}28.3 \\
29.8 \\
27.3 \\
26.8 \\
30.5 \\
28.3\end{array}$ & $\begin{array}{l}16.6 b^{2} \\
16.9 b^{\prime} \\
18.7 a\end{array}$ & $\begin{array}{l}383 \mathrm{a} \\
374 \mathrm{a} \\
316 \mathrm{~b} \\
348 \mathrm{ab} \\
376 \mathrm{a} \\
378 \mathrm{a}\end{array}$ & $\begin{array}{l}239 \mathrm{c} \\
263 \mathrm{~b} \\
304 \mathrm{a}\end{array}$ & $\begin{array}{l}7.2 \\
6.9 \\
6.6 \\
6.9 \\
7.1 \\
6.8\end{array}$ & $\begin{array}{l}5.6 \mathrm{~b} \\
5.7 \mathrm{~b} \\
6.5 \mathrm{a}\end{array}$ & $\begin{array}{l}4.7 \mathrm{a} \\
4.4 \mathrm{a} \\
4.0 \mathrm{~b} \\
3.9 \mathrm{~b} \\
4.8 \mathrm{a} \\
4.0 \mathrm{~b}\end{array}$ & $\begin{array}{l}3.8 \mathrm{c} \\
4.4 \mathrm{~b} \\
4.8 \mathrm{a}\end{array}$ & $\begin{array}{l}32.0 \mathrm{~b} \\
32.9 \mathrm{~b} \\
34.8 \mathrm{a}\end{array}$ \\
\hline
\end{tabular}

Wean separation in columns by LSD test, $P=0.05$. No significant differences in column without letters.

${ }^{\mathrm{y}} 1=$ poor, $5=$ excellent quality.

and Ball II media, but reduced almost two-thirds in the finertextured Metro Mix 350.

Growth measurements of chrysanthemums in both experiments are presented in Table 4. Comparisons in Expt. 1 show that rockwool medium 3 performed poorest in all characteristics measured. Rockwool media 1 and 2 were, on the whole, nearly equal to each other and somewhat better than medium 3. The best rockwool medium was mix 4 . In terms of plant height and width, medium 4 was equal to medium 5 (commercial); however, number of flowers produced, plant fresh weight, and qual- ity ratings were lower for the rockwool medium. Medium 6 (commercial) outperformed all other media tested. In Expt. 2, rockwool medium 4 performed equal to medium 5 for all characteristics. Again, medium 6 performed better than the other media, except for plant width, where it was equal.

All media performed equally well for geranium in Expt. 1, with a few exceptions (Table 5). The fresh weight of plants in medium 3 was lower than in all other media and the quality ratings of plants in media 3,4 , and 6 were equal to each other, and less than those in the remaining media. In Expt. 2, medium 
Table 6. The effect of root media treatments on characteristics of 'Dark Red Annette Hegg.' poinsettia ${ }^{\mathrm{z}}$

\begin{tabular}{|c|c|c|c|c|c|c|c|c|c|}
\hline \multirow[b]{3}{*}{ Medium } & \multirow{3}{*}{$\begin{array}{c}\text { Rockwool } \\
(\%)\end{array}$} & \multicolumn{8}{|c|}{ Experiment } \\
\hline & & 1 & 2 & 1 & 2 & 1 & 2 & 1 & 2 \\
\hline & & Heig & $\mathrm{t}(\mathrm{em})$ & Fre & $\mathrm{wt}(\mathrm{g})$ & Inflor & (No.) & Inflorescence & (diam) \\
\hline $\begin{array}{l}1 \\
2 \\
3 \\
4 \\
5 \\
6\end{array}$ & $\begin{array}{r}10 \\
20 \\
30 \\
20 \\
0 \\
0\end{array}$ & $\begin{array}{l}41.3 \\
40.8 \\
41.2 \\
40.8 \\
41.3 \\
39.6\end{array}$ & $\begin{array}{l}34.5 \\
36.2 \\
36.7\end{array}$ & $\begin{array}{l}229 \\
210 \\
217 \\
204 \\
207 \\
209\end{array}$ & $\begin{array}{l}222 b^{2} \\
256 a \\
264 a\end{array}$ & $\begin{array}{l}7.4 \\
7.3 \\
7.2 \\
6.6 \\
7.2 \\
6.9\end{array}$ & $\begin{array}{l}8.1 \\
8.0 \\
8.6\end{array}$ & $\begin{array}{l}28.5 \\
28.7 \\
28.9 \\
29.8 \\
29.7 \\
29.4\end{array}$ & $\begin{array}{l}27.5 \mathrm{~b} \\
30.0 \mathrm{a} \\
28.3 \mathrm{~b}\end{array}$ \\
\hline
\end{tabular}

${ }^{\mathrm{z}}$ Mean separation in columns by LSD test, $P=0.05$. No significant differences in column without letters.

Table 7. Effect of root medium on height and weight of individual plants of four bedding plant species. ${ }^{\mathrm{Z}}$

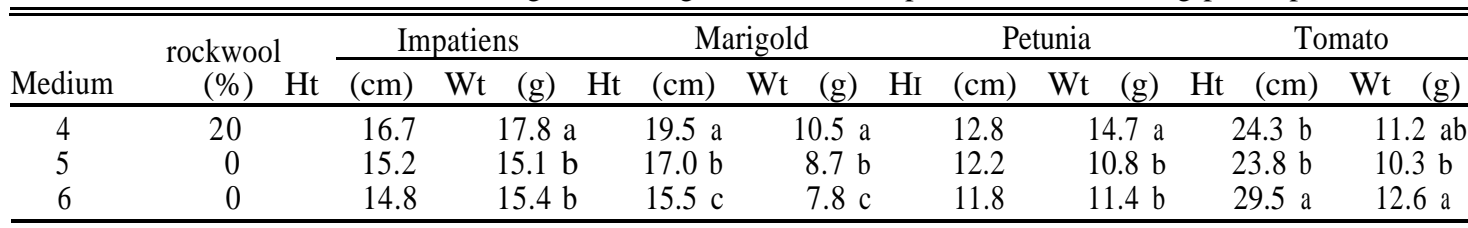

${ }^{\mathrm{z}}$ Mean separation in columns by LSD test, $P=0.05$. No significant differences in column without letters.

Table 8. Nutrient content of recently mature leaves of four bedding plant species grown in various root media treatments at the end of the second experiment. ${ }^{\mathrm{Z}}$

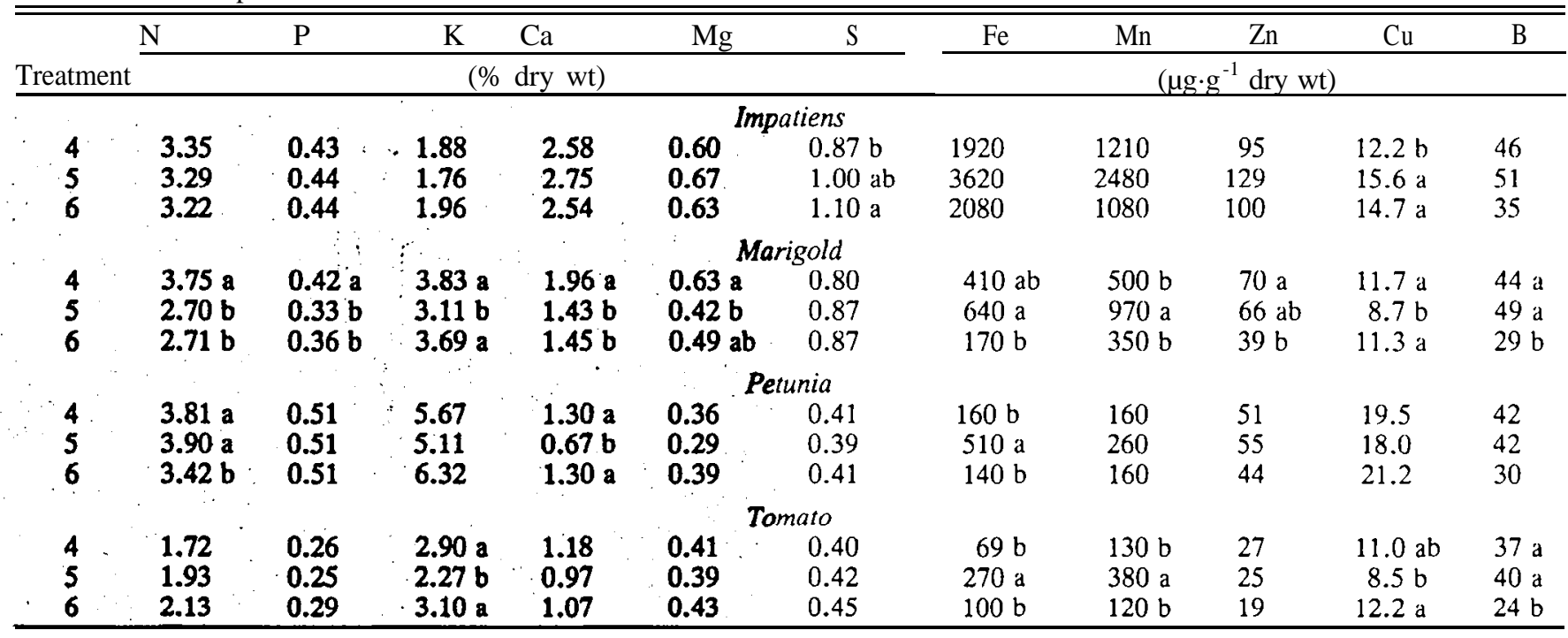

${ }^{\mathrm{z}}$ Mean separation within columns, species, and nutrients by LSD test, $P=0.01$. No significant differences in column without letters.

6 was best in terms of all characteristics. Plants grown in rockwool medium 4 were as tall and wide and produced an equal number of shoots as plants in medium 5 but had a lower fresh weight and rating.

Poinsettia growth in Expt. 1 was equal in all respects, regardless of medium (Table 6). In Expt. 2, growth again was equal, except that the fresh weight of plants grown in the rockwool medium 4 was lower, and the bract diameters of plants grown in media 4 and 6 were lower than in the others. Considering all three plant species tested, the best rockwool blend was medium 4, which contained $20 \%$ rockwool and $10 \%$ peatmoss. The poorest blend contained $30 \%$ rockwool and no peatmoss. Media 4 and 5 were fairly similar. Slight decreases in fresh weight and quality rating for medium 4 were not consistent over experiments and species.

The height of impatiens and petunia plants grown in medium 4 were equal to plants in media 5 and 6 (Table 7). While the fresh weights of plants in media 5 and 6 were equal, weights were higher in rockwool medium 4, which resulted in more desirable, stockier plants. Marigold plants increased in both height and fresh weight in the order media $6 \rightarrow 5 \rightarrow 4$. Since plant proportion was maintained, the production time was shortest in the rockwool medium, making it the most desirable. Tomato plants in media 4 and 5 were equal in height and width. The height and width of plants in medium 6 were greater, thus presenting the possibility of earlier commercial production in that medium. In general, the growth of bedding plants in rockwool medium 4 was superior to commercial media 5 and 6 , except for tomato, for which it was equal to medium 5 .

The superior performance of the rockwool medium for bedding plants may relate to: 1) a lower water content in the rockwool medium, or 2) a shift in the phase distribution of air and water content within the medium. Either of these could be a decided advantage in the shallow bedding plant cells. There was 
Table 9. Root media $\mathrm{pH}$ levels on various days after planting for four bedding plant species tested in both experiments.

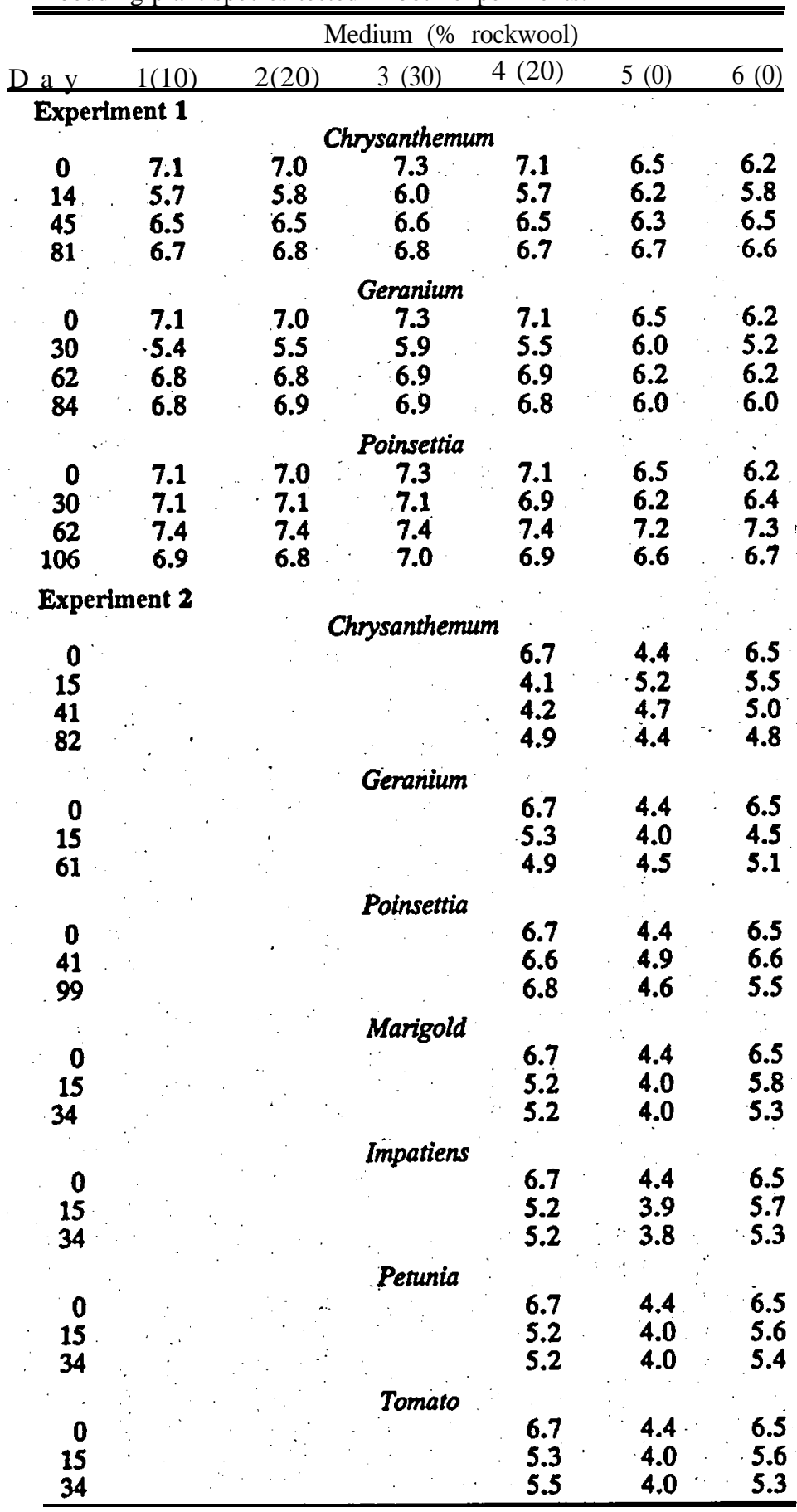

clearly more air content in the rockwool medium than in medium 6, which could improve seedling establishment. Although the air content of the rockwool medium was similar to that of medium 5, the container capacity and available water content was less in the rockwool medium. This relationship indicates a change in the way water is distributed within the container. The rockwool medium had greater air content in the upper region of the container and more water further down. This higher air content in the top portion of the container could provide a more favorable environment for root establishment. The occasionally poorer performance of the rockwool media for plants grown in 1.58-liter pots probably relates to lower soil solution retention,
Table 10. Nitrate nitrogen expressed as a percent of the total nitrogen (nitrate, ammonium, and urea) extracted from root media in Expt. 1 by the saturated soil extract procedure at various times after planting

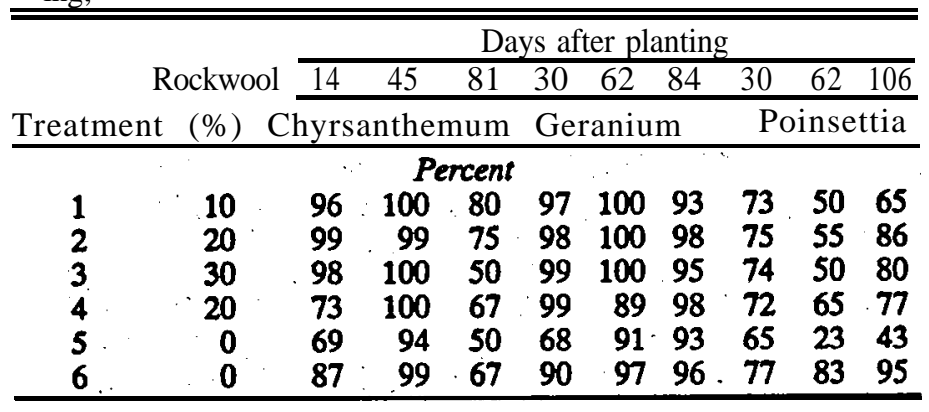

which might be remedied by more frequent watering or increasing nutrient content of the soil solution.

Explanation of the different responses of chrysanthemum, geranium, and poinsettia plants to the media could not be found in leaf nutrient composition. Although tissue content differences did occur, the ranges of nutrient concentrations were within acceptable limits for the three species (Ball, 1985; Criley and Carlson, 1970; Ecke and Matkin, 1976; Hanan et al., 1978; Holcomb and White, 1982; Kofranek, 1980; Mastalerz, 1977; Nelson, 1985). No consistent trends in nutrient concentrations could be found related to either the proportion of rockwool in the medium or to the comparison of rockwool media to commercial media. However, there were media $\mathrm{pH}$ effects on $\mathrm{Mn}$ and $\mathrm{Zn}$ concentrations to be addressed later.

Nutrient concentrations of the youngest fully expanded leaves of four bedding plant species tested in Expt. 2 are presented in Table 8. All nutrient concentrations were adequate. No consistent shifts occurred in nutrient concentration of plants grown in the rockwool medium to account for departures in growth from plants in the commercial media, with the exception of $\mathrm{Mn}$ in marigold and $\mathrm{Mn}$ and possibly $\mathrm{Zn}$ in impatiens. The Mn level in marigold leaves of plants in medium 5 appeared to be high (963 mg.g $\mathrm{g}^{-1}$ ); however, neither chlorosis nor necrosis symptoms, typical of Mn toxicity, developed. Leaf concentrations of Mn for impatiens in all three media were high. The highest level $\left(2480 \mathrm{mg} \cdot \mathrm{g}^{-1}\right)$ occurred in the plants in medium 5 and was associated with symptoms that had progressed over 19 days. Recently matured leaves were affected first. These leaves were chlorotic, stunted, tended to curl down at the margin, and developed necrotic spots across the leaf blade, with the highest density along the margins. This syndrome is typical of Mn toxicity. Recently matured leaves on plants in medium 6 were slightly chlorotic, while only a few leaves in those of medium 4 were chlorotic. Plants in media 4 and 6 appeared to be at incipient levels of Mn toxicity and had leaf Mn concentrations of 1210 and $1080 \mathrm{mg} \cdot \mathrm{g}^{-1}$, respectively. Levels of $\mathrm{Zn}$ were also noted to be high in impatiens leaves. Whether this condition contributed to the overall symptoms cannot be ascertained because the upper critical $\mathrm{Zn}$ level is not known for this crop.

The initial pH levels (Table 9) of rockwool media 1 to 4 were higher than desired in Expt. 1, but quickly decreased to acceptable levels for chrysanthemum and geranium. In contrast, the $\mathrm{pH}$ levels in the media with poinsettia remained too high throughout Expt. 1. Commercial media 5 and $6 \mathrm{pH}$ levels were in a desirable range in Expt. 1, except for poinsettia at 62 days after planting, when levels were too high. Differences in $\mathrm{pH}$ levels among the rockwool media or between the rockwool and 
commercial media were very small and do not explain the different responses obtained for chrysanthemum and geranium plants. While there were differences in $\mathrm{pH}$ levels among media with poinsettia in Expt. 1, there were no plant response differences.

The initial $\mathrm{pH}$ level of medium 6 in Expt. 2 was desirable and remained so for all plant species except chrysanthemum, for which it dropped to a low level at harvest time, and for geranium, where it was low only 15 days after planting. The $\mathrm{pH}$ of rockwool medium 4 was initially 6.7 in Expt. 2, which was much more desirable than 7.1 in Expt. 1. This difference can be explained by the decrease in limestone rate from 3.6 $\mathrm{g} \cdot \mathrm{m}^{-3}$ in Expt. 1 to $1.8 \mathrm{~g} \cdot \mathrm{m}^{-3}$ in Expt. 2. However, the $\mathrm{pH}$ levels generally decreased to lower levels in the second experiment. For chrysanthemum, the levels were too low, while, for all other plants except poinsettia, the $\mathrm{pH}$ levels were safe but close to the lower limit (Larson, 1980). As in Expt. 1, pH levels in the media with poinsettia were higher than in the media for any other plants. Adequate levels of $\mathrm{Ca}$ were accumulated in all plant species grown in medium 4, most likely because calcium sulfate was incorporated into this medium during its formulation. Medium 5 was too low in $\mathrm{pH}$ at the start of Expt. 2, and remained so for all plants, which could explain its poorer performance compared to medium 6 .

The abnormally high levels of $\mathrm{Mn}$ in Expt. 2 in marigold and impatiens and of $\mathrm{Zn}$ in impatiens (Table 8) relates well to the low media $\mathrm{pH}$ levels (Table 9). Moderately high $\mathrm{Mn}$, concentrations of $, 363,637$, and $526 \mu \mathrm{g} \cdot \mathrm{g}^{-1}$ dry weight were found in chrysanthemum leaves in Expt. 2 for media 4, 5, and 6, respectively. Tissue levels of Mn were highest in plants grown in medium 5, which also had the lowest $\mathrm{pH}$ levels. It is noteworthy that impatiens is a heavy accumulator of $\mathrm{Mn}$ and $\mathrm{Zn}$, while marigold and chrysanthemum are moderately heavy accumulators of $\mathrm{Mn}$.

The higher media $\mathrm{pH}$ levels that occurred with poinsettia indicated the possibility of unusually high nitrate accumulation. This was borne out in the first experiment (Table 10). Although the same proportion of nitrate to ammonium was applied to each plant species and medium; the fraction of nitrate remaining in the soil solution was generally lower for poinsettia than for chrysanthemum or geranium. This difference indicated a higher affinity for nitrate in poinsettia. Thus, plant species can exert an effect on medium $\mathrm{pH}$ in addition to the effects of the physical components of the media.

Rockwool has excellent potential as a new component for container substrates. The physical properties of rockwool are unique among substrate components. The total porosity $(0 \mathrm{kPa})$ of rockwool alone is higher than any other component or mix available for production, with peatmoss being the closest. Rockwool releases more water between 0 and $30 \mathrm{kPa}$ than any of the other components or mixes. Rockwool has the lowest water holding content at tensions $\geq 30 \mathrm{kPa}$, with sand being the closest. These characteristics ultimately translate into a component that can increase both water-holding capacity and aeration.

The plants grown in the rockwool-containing mix (medium 4), on average, performed equally well as the commercial mixes. Growth responses across experiments and plant species ranged from slightly inferior. to slightly superior for medium 4. More work is needed to better define formulations of rockwool-containing substrates.

\section{Literature Cited}

Ball, V. (ed.). 1985. Ball redbook. 14th ed. Reston Publ. Co., Reston, $\mathrm{Va}$.
Bilderback, T.E. and W.C. Fonteno. 1987. Effects of container geometry and media physical properties on the air and water volumes in containers. J. Environ. Hort. 5(4):180-182.

Cataldo, D.A., M. Haroon, L.E. Schrader, and V.L. Youngs. 1975. Rapid colorimetric determination of nitrate in plant tissue by nitration of salicylic acid. Commun. Soil Sci. Plant Anal. 6(1)71-80.

Chaney, A.L. and E.P. Marbach. 1962. Modified reagents for determination of urea and ammonia. Clin. Chem. 8(2):130-132.

Criley, R.A. and W.H. Carlson. 1970. Tissue analysis standards for various floricultural crops. Florists' Rev. 146:19-20, 70-73.

Eastin, E.F. 1978. Total nitrogen determination for plant material containing nitrate. Anal. Biochem. 85:591-594.

Ecke, P., Jr., and O.A. Matkin (eds.). 1976. The poinsettia manual. Paul Ecke Poinsettias, Encinitas, Calif.

Fonteno, W.C., D.K. Cassel, and R.A. Larson. 1981. Physical properties of three container media and their effect on poinsettia growth. J. Amer. Soc. Hort. Sci. 106(6):736-741.

Grinstead, R.R. and S. Snider. 1967. Modification of the curcumin method for low level boron determination. Analyst 92:532-533.

Hamrick, D. 1985. Rockwool: controlling plant nutrients hydroponically. Grower Talks. Apr. 1985. p. 75-80.

Hanan, J.J. 1983. Use of rockwool as a potting mixture comparison with peat moss, soil and vermiculite. Colorado Greenhouse Growers' Assn. Bul. 395:1-5.

Hanan, J.J., W.D. Holley, and K.L. Goldsberry. 1978. Greenhouse management. Springer-Verlag, New York.

Holcomb, E.J. and J.W. White. 1982. Fertilization, p. 58-75. In: J.W. Mastalerz and E.J. Holcomb (eds.). Geraniums III. Pa. Flower Growers, University Park.

Jackson, M.L. 1958. Soil chemical analysis. Prentice-Hall, Englewood Cliffs, N.J. p. 151-154.

Karlovich, P.T. and W.C. Fonteno. 1986. Effects of soil moisture tension and soil water content on the growth of chrysanthemum in 3 container media. J. Amer. Soc. Hort. Sci. 111:191-195.

Klute, A. 1986. Water retention: laboratory methods, p. 635-662. In: A. Klute (ed.). Methods of soil analysis, Part 1. Physical and mineralogical methods. Amer. Soc. Agron., Madison, Wis. Monogr. 9.

Kofranek, A.M. 1980. Cut chrysanthemums, p. 3-45. In: R.A. Larson (ed.). Introduction to floriculture. Academic, New York.

Larson, R.A. (ed.). 1980. Introduction to floriculture. Academic, New York.

Lee, C.W. and K.L. Goldsberry. 198. Evaluation of loose rockwool as a growing medium for geraniums: comparison with peat-lite and soil mixes. Colorado Greenhouse Assn. Bul. 459:1-3.

Lee, C.W., K.L. Goldsberry, and J.J. Hanan. 1987a. Evaluation of loose rockwool as a growing medium for pot chrysanthemums: comparison with peatlite and soil mixes. Colorado Greenhouse Assn. Bul. 439:2-3.

Lee, C.W., K.L. Goldsberry, and J.J Hanan. 1987b. Evaluation of loose rockwool as a growing medium for poinsettia: comparison with peatlite and soil mixes. Colorado Greenhouse Assn. Bul. 441:1-2.

Mastalerz, J.W. 1977. The greenhouse environment. Wiley, New York. p. $512-515$.

Milks, R.R., W.C. Fonteno, and R.A. Larson. 1989. Hydrology of horticultural substrates: I. Mathematical models for moisture characteristics of horticultural container media. J. Amer. Soc. Hort. Sci. 114:48-52.

Milks, R.R., W.C. Fonteno, and R.A. Larson. 1989. Hydrology of horticultural substrates: II. Predicting physical properties of media in containers. J. Amer. Soc. Hort. Sci. 114:53-56.

Nelson, P.V. 1985. Fertilization, p. 182-204. In: J.W. Mastalerz and E.J. Holcomb (eds.). Geraniums III. Pa. Flower Growers, University Park.

Van Genuchten, M.T. and D.R. Nielson. 1985. On describing and predicting the hydraulic properties of unsaturated soils. EGS; Ann. Geophys. 3:615-628.

Warncke, D.D. 1986. Analyzing greenhouse growth media by the saturation extraction method. HortScience 21:223-225. 